\title{
The Finiteness of Crude Oil: Are We
}

\section{Running Out?}

\section{Conor Smith}

Department of Department of Food, Agricultural and Resource Economics, University of Guelph, Guelph, ON Canada. Faculty supervisor: Dr. Glenn Fox. For correspondence, please email: csmith59@uoguelph.ca.

\section{Abstract}

Oil is a controversial natural resource. One aspect of its controversial nature takes the form of periodic expressions of fear at the prospect of the depletion of this energy source, often referred to as Peak Oil Theory. Julian Simon was among the first to challenge the increasing scarcity scenario and argued that global oil stocks are increasing as a result of anthropogenic activity. He presented evidence that, since the $1860 \mathrm{~s}$, oil prices had been generally decreasing. Bjørn Lomborg set out to challenge Simon's finding, and ultimately ended up siding with Simon, concluding that crude oil stocks are increasing and that there is no sign that the world will soon "run out" of this finite resource. This paper updates the earlier work by Simon and Lomborg to see if the trends that they documented have changed since their research was published. Updated data are presented on oil prices, stocks, and extraction rates. These updated data suggest that most of Simon and Lomborg's findings still hold. The analysis provided in this report concludes that the depletion of oil stocks is not of utmost concern, and that continuous technological innovation allows for greater output per unit of crude oil consumed, thus essentially increasing the availability of crude oil, and giving new meaning to the term "finite" in the realm of natural resources. Of course, future alternatives are important to discuss, as issues associated with oil dependency remain relevant. But fears of running out of this resource seem to be unjustified.

Keywords: Julian Simon, Bjørn Lomborg, crude oil, The Ultimate Resource, The Skeptical Environmentalist, Peak Oil Theory

\section{Introduction}

Julian Simon (1998), an American university professor and economist, once described human capital as the 'ultimate resource' and energy as the 'master resource'. It has been widely accepted throughout recent decades that crude oil is being depleted and that the world will soon run out of this non-renewable energy source. Simon (1998) was one of the first economists to question fears of oil depletion as being inconsistent with historical data. $\mathrm{He}$ concluded that not only was the world not running out of crude oil reserves, but that they were instead becoming more abundant. Bjørn Lomborg, a Danish author and statistician, set out to challenge Simon's views (Norgaard, 2002), but ended up confirming Simon's findings (Van Den Bergh, 2010). When Lomborg's book, The Skeptical Environmentalist, was published, he was challenged by various experts in the field and widely scrutinized by academics who believed that his findings were fabricated and baseless (Van Den Bergh, 2010). However, these criticisms and accusations were highly unsubstantiated, and were ultimately dismissed (Fog, 2005).

The purpose of this paper is to revisit Simon and Lomborg's findings to see if the trends that they documented have changed in recent years. The paper is broken down into three sections. The first section reviews
Simon's work. The second section provides a summary of Lomborg's research. The third and final part of this paper presents updated data on price and availability trends that Simon and Lomborg analyzed, addressing fears of scarcity defined by Marion King Hubbert's widely accepted Peak Oil Theory (Bardi, 2009).

\section{The Ultimate Resource}

Julian Simon, author of The Ultimate Resource 2, (1998) was among the first to question the validity of the widely held idea that crude oil and non-renewable resources are being depleted to the point of economic exhaustion. It is one thing to observe that oil deposits are a finite quantity. It is another thing to conclude that the economic exhaustion of that finite quantity is imminent. Simon (1998) observed that the rapid increase in crude oil prices at the time he was writing, in the mid-1970s and early 1980s, was not consistent with price trends over the past century. He concluded that the constant price of crude oil was slowly decreasing over time. Simon (1998) puts this situation as follows: 
The Finiteness of Crude Oil: Are We Running Out? (Smith)

The historical facts entirely contradict the commonsensical Malthusian theory that the more we use the less there is left to use and hence the greater the scarcity. Through the centuries, the prices of energy - coal, oil, and electricity - have been decreasing rather than increasing, relative to the cost of labor and even relative to the price of consumer goods, just as with all other natural resources. And nuclear energy, which at present costs much the same as coal and oil, guarantees an inexhaustible supply of energy at declining cost as technology improves. (p. 180)

Data on crude oil prices do exhibit variations over time, reflecting times of war, cartel pricing, and technological innovation (Gholz \& Press, 2007; British Petroleum, 2015; Plains All American Pipeline, 2017). However, according to Simon, the underlying trend in constant dollar prices raises no cause for concern.

Simon's explanation for the long-term trend in constant oil prices is laid out in chapter 11 of The Ultimate Resource 2. His argument was that market forces influence the supply and demand of oil, and that increases in human capital and technological innovation had occurred more quickly than the rate of oil consumption (Simon, 1998). Simon's findings suggest that per unit output of crude oil increases at a faster rate than unit extraction, forecasting an exponentially growing supply of crude oil (Simon, 1998).

If Simon's findings are correct, then the widespread fears of energy shortage would appear to be unjustified. However, even unjustified fears can have real consequences. Gholz and Press (2007) studied the implications of the growing fear in the U.S. that oil is running out. Exaggerated fears surrounding oil supplies create unwarranted, often harmful U.S. foreign and military policy (Gholz \& Press, 2007). The U.S. government is preoccupied with China's attempt to monopolize remaining oil supplies as well as political issues within unstable oil-rich countries, costing them financial and capital resources that could otherwise be allocated to projects in reduced oil-extraction costs (Gholz $\&$ Press, 2007). Data presented by Gholz and Press (2007) show that U.S. military presence on foreign soils only aggravates political problems instead of solving them, provoking wars and civil conflicts. Additionally, they show that China's monopolization of oil reserves may ultimately increase oil availability for the U.S. through foreign policy adjustments (Gholz \& Press, 2007).

It is merely because of baseless anxieties surrounding the finiteness of crude oil supplies that governments have become increasingly involved in the policy implementation, planning, and controlling of crude oil extraction projects, resulting in price spikes (Simon, 1998). Simon concluded that such government programs created artificial scarcity and drove up prices of oil, which would have otherwise - judging by historical trends - decreased continuously with technological innovation (Simon, 1998).

\section{The Skeptical Environmentalist}

In the fall of 1997, Danish statistician and author Bjørn Lomborg set out to challenge Julian Simon's conclusions on the finiteness of the world's non-renewable energy sources (Van Den Bergh, 2010). Lomborg was ultimately unsuccessful in his quest to refute Simon's views, and instead ended up confirming Simon's findings (Van Den Bergh, 2010). Lomborg intended for his 1998 book to be a rebuttal of The State of the World, a yearbook produced annually by the Worldwatch Institute (WWI). In 2001, the English version of Lomborg's book, The Skeptical Environmentalist, was published, sparking global debate among scientists and various others in the field (Van Den Bergh, 2010). The Skeptical Environmentalist raises issues surrounding the availability of foods, forests, energy, freshwater, and biodiversity, as well the reality behind pollution levels, and the true implications of global warming (Pimm \& Harvey, 2001). Lomborg (2001) concludes:

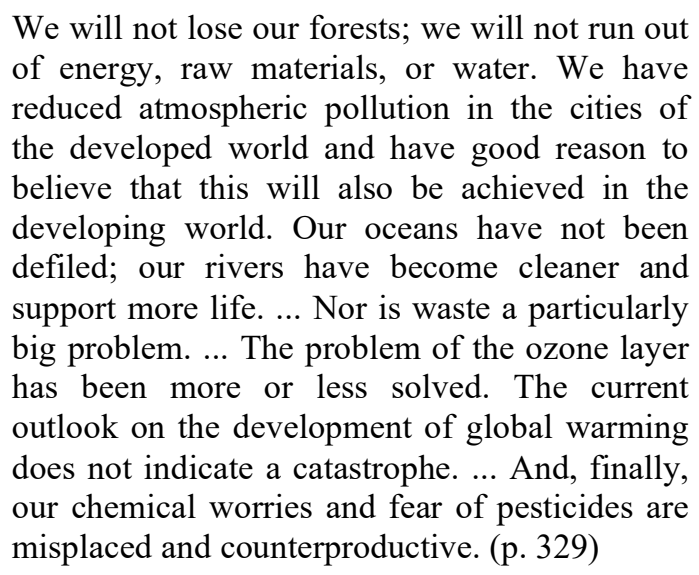

As might be expected, much of the scientific community responded with negative reactions to Lomborg's claims (Van Den Bergh, 2010). Much of what Lomborg claims in the quotation above is considered to be far-fetched by other naturalists and experts in the field (Van Den Berg, 2010). Undoubtedly, some of his views are provocative, and the true extent of resource scarcity remains contentious. That being said, Lomborg's ideas presented in The Skeptical Environmentalist certainly provoke thought and productive conversation surrounding the true state of the planet's finite energy resources (de Groost \& Hoekstra, 2002). The majority of Lomborg's critics accused him of neglecting to include unbiased regional trends in resource availability in his data, using data selectively to favour his conclusions, and citing unreliable sources (Cole, 2003; Rohlf, 2002). However, these accusations were never fully substantiated, and his critics never provided sufficient evidence to suggest his 
findings were, in fact, fabricated (Fog, 2005). Nonetheless, in January of 2003, the Danish Committees on Scientific Dishonesty (DCSD) concluded that The Skeptical Environmentalist had committed scientific dishonesty (Van Den Bergh, 2010). However, in December of 2003, the conclusions made by the DCSD were deemed invalid by the Danish Ministry of Research (DMR), as Lomborg's critics were shown to have fabricated biased data of their own to refute claims made in The Skeptical Environmentalist, and were not legally permitted to judge the objective validity of Lomborg's research (Fog, 2005; Van Den Bergh, 2010). Having said this, heavy scrutiny on both sides of the Lomborg controversy has all but silenced the topic of scarcity, creating incentives to research and provide objective data on current crude oil trends.

This paper provides updated data on crude oil for the years since Simon and Lomborg published their research. For example, Figure 1 presents data on proven crude oil reserves from 1980-2017, showing that proven reserves have continued to increase for the period after 2001, when The Skeptical Environmentalist was published, reflecting Simon (1998) and Lomborg's (2001) predictions for future reserves accurately. Further interpretation of the data provided in this paper will be discussed in the next section.

\section{Observed Trends in the Crude Oil Industry Since the $20^{\text {th }}$ Century}

\section{Availability}

Simon (1998) and Lomborg's (2001) research provided substantial evidence suggesting that crude oil stocks are - to the surprise of many-increasing, as opposed to decreasing. That being said, one theory that was popularized in the late $20^{\text {th }}$ century is Marion King Hubbert's Peak Oil Theory (Bardi, 2009). Hubbert's theory suggests that the production curve of crude oil is a symmetrical bell-curve, indicating that we will reach-or perhaps have reached - peak crude oil production levels in the early $21^{\text {st }}$ century, and that reserves are gradually running out (Bardi, 2009). However, looking at the historical data, we can see that this theoretical production bell-curve is steadily shifting to the right as experts continue to make predictions as to when crude oil will effectively run out (Blankart, 2017). This further supports Simon (1998) and Lomborg's (2001) findings that fears of the finiteness of oil were, and still are, unsupported by evidence and empirical data.

Analyzing updated data since Simon and Lomborg published their research, we can see that much of what they found remains true today. This is projected in Figure 1, which presents estimates of total proven oil reserves globally from 1980-2017. Data in the figure were obtained from British Petroleum (2018). Proven Reserves are defined by the Organization of the Petroleum Exporting Countries (OPEC) as the quantity of crude oil that is readily recoverable now and in the future using current extraction techniques (OPEC, 2001). Knowing the location and volume of current available crude oil, alongside knowledge of historical trends, allows prices and future reserves to be predicted, thus allowing markets and individual firms to respond appropriately to present crude oil data. Presenting contemporary data on crude oil prices, availability, and reserve locations mitigates the effects of damaging precautionary government policy, as mentioned earlier by Gholz and Press (2007). As shown in Figure 1, proven reserves increased steadily from 1980 until 2017 (British Petroleum, 2018). What is important to note is that, despite data reflected in Figure 1, fears of oil scarcity were dominant throughout society in the mid- $20^{\text {th }}$ century (Watkins, 2006). In fact, predictions of the world effectively 'running out' of crude oil reserves before the $21^{\text {st }}$ century were popular (Watkins, 2006). Figure 1 notes that there were an estimated 684 billion barrels in proven crude oil reserves in 1980 (British Petroleum, 2018). Moreover, global production exceeded 62.9 million barrels per day (British Petroleum, 2018). This data is significant because almost forty years later, in 2017 , there were an estimated 1,727.5 billion barrels of proven reserves of crude oil remaining in the world and the daily production rate was approximately 92.5 million barrels per day (British Petroleum, 2018). This data reflects an increase in daily production of roughly 48\% since 1980 (British Petroleum, 2018). So how is it that after 37 years, estimated proven crude oil reserves nearly tripled? This increase in global proven reserves over the past four decades certainly provokes thought surrounding the widely held notion that oil reserves will soon run out. The answer to this question is, ultimately, that technology has improved faster than oil has been consumed (Watkins, 2006; British Petroleum, 2018). It is only logical to predict that the global stock of finite natural resources will decline as they are consumed at increasing rates. However, one factor that has proven to be quite unpredictable is technological advancement and human innovation (Watkins, 2006). Watkins (2006) simply points out the fact that previous claims projecting that oil wells would dry up omitted accounting for potential cost-effective and efficient improvements in extraction methods and consumption rates. Watkins' claims are supported by the data in Figure 1, which display continuously rising crude oil reserves as consumption increases and technology improves (British Petroleum, 2018). Figure 2 illustrates estimated levels of global crude oil production from 19722016 measured in thousand Metric Tons of oil equivalent (TOE). TOE is a measurement used to assess the amount of energy produced per metric ton of oil burned (Eurostat, 2016). There has been a steady, almost linear upward trend of global crude oil production from 1972-2016, as shown in Figure 2. This further supports Simon's (1998) findings on future crude oil availability based on historical trends. Figure 2 ultimately balances the increasing ingenuity and efficiency of human capital against the notion of 
diminishing reserves. While finite reserves may be, by definition, limited, human ingenuity so far appears boundless. The only way in which the world will 'run out' of crude oil will be if market prices become so high thatassuming alternative fuels are available - it would be an essentially unaffordable product (Pannell, 2011). This scenario would only unfold if - as outlined by David Pannell (2011) - crude oil production rates started to steadily decrease to the point where it became unaffordable. However, seeing as the historical trends in crude oil production and availability as predicted by Simon (1998) hold true today, and given that it holds true in the near future, crude oil stocks are not likely to decline at such a rapid rate - if at all — in the foreseeable future.

\section{Pricing}

Simon (1998) and Lomborg (2001) observed that, contrary to expert and popular opinion, the global price of crude oil was actually decreasing in constant terms rather than increasing. Observing changes in the nominal price of oil fails to take the effects of inflation into account. Converting nominal prices into real or constant dollar prices, through something like the Consumer Price Index (CPI), gives a more meaningful measure of price trends for oil. The CPI is calculated by averaging the annual prices of a fixed set of consumer goods, thus allowing us to measure true annual price fluctuations in constant dollars, accounting for inflation. That is to say that the upward trend in nominal prices of crude oil over the past century is not atypical in comparison to any other consumer good. This makes the argument of increasing crude oil prices over time weak-and truthfully, invalid-according to historical data (Simon, 1998; Lomborg, 2001).

Figure 3 shows crude oil prices in nominal and constant terms from 1861-2017 in U.S. dollars. Current data on crude oil price trends are not entirely reflective of Julian Simon's (1998) argument that oil prices are gradually diminishing over time. The data in Figure 3 shows a rather steady trend in nominal and constant prices over time, up until the 1970s. However, the trend of the line representing constant prices over time is slightly flatter than that of the nominal prices, showing that prices have been gradually increasing, and that they have remained relatively low over the past century and a half, despite proclamations of rapidly increasing oil prices (Simon, 1998; Lomborg, 2001). That being said, the data in Figure 3 show significant oscillations in prices over the past century. Gholz and Press (2007) attribute these trends in oil prices primarily to market forces, producer cartel behaviour, economic downturns, and occasionally, war. For example, the rapid price increase of crude oil in the late 1800 s is reflective of monopoly price setting by the market-controlling oil company, John D. Rockefeller Standard Oil (McGee, 1958). The monopolistic hold John D. Rockefeller Standard Oil had over the global market slowly diminished when other crude oil producing firms arose in light of high demand for the product, as is reflected by the gradual decrease in constant prices in Figure 3 (McGee, 1958). Figure 3 also illustrates that constant oil prices spiked in the early 1970s, and again in the early 1980s before collapsing in the late 1990s. Barsky and Killian (2004) accredited this rapid increase in constant prices of crude oil in the 1970s and 1980s to the Iran-Iraq war, explaining that the conflict disrupted the supply and distribution of oil from those regions before prices fell back down in early 1990s at the end of the conflict when the market returned to full operational capacity. Finally, as shown in Figure 3, prices spiked again in 2006, rapidly fell back down in 2008, rose again in 2011, fell in 2013, and started increasing again in 2015. The significant price fluctuations during this time period in recent history are reflective of crude oil-availability scares stemming from the U.S. housing market crash and low spare crude oil capacities reported by the Organization of the Petroleum Exporting Countries (OPEC), and are not indicative of true crude oil availability in global reserves (Arezki et al., 2017). In fact, according to historical trends in crude oil price data shown in Figure 3, it is possible that crude oil prices will begin to decrease again in the near future. However, it is important to note that crude oil prices have proven to be quite volatile, and future trends in pricing cannot be predicted with certainty using solely historical observations. Given this, Simon and Lomborg's argument that oil prices are constantly diminishing cannot be entirely supported.

\section{Conclusion}

Despite Julian Simon's (1998) conclusions, it is still a widely held belief that the world is simply running out of crude oil stock and that reserves will soon run dry. However, upon analyzing past and current data showing current proven crude oil reserves, illustrated in Figure 1, the trends suggest that the availability of oil is, from an economic perspective, increasing, so long as human capital and innovation increases at a faster rate than the extraction of crude oil (Simon, 1998). Furthermore, data projected by Figure 2, which displays the rates of production of crude oil from 1976-2016, supports findings that crude oil production will only increase in conjunction with increasing rates of human capital (Simon, 1998; Watkins, 2006). Moreover, Figure 3, which displays constant and nominal prices of crude oil over time in the forms of annual price fluctuations, suggests that the constant price of oil is increasing by a much smaller degree than was previously conceived. While the current data does not entirely reflect Simon and Lomborg's argument of diminishing oil prices, there is no evidence that the world is 'running out' of oil or that prices will rapidly increase in the near future. My findings ultimately confirm the conclusions of Simon and Lomborg with respect to crude oil availability for the years that have passed since they published their research. Current and historical data do not suggest that the world will run out of 
crude oil any time soon (Morris, 2002). That being said, it is important to note that alternative fuels have been steadily emerging. Further research into the efficiency and reliability of alternative fuels such as natural gasses - which are thought to leave a smaller carbon footprint than fossil fuels-is certainly relevant and should be explored further in future studies (Hekkert et al., 2003). However, given that Simon's findings on crude oil availability still hold true, prioritizing the subsidization of research into alternative fuels over current practices in oil extraction lowers productivity in the energy industry (Morris, 2002).

\section{Acknowledgements}

I would like to thank Dr. Glenn Fox from the department of Food, Agricultural and Resource Economics for supervising this independent research study and for providing me with guidance along the way. Please note that the content and conclusions outlined in this study are reflective solely of the author's findings and opinion.

\section{References}

Arezki, R., Jakab, Z., Laxton, D., Matsumoto, A., Nurbekyan, A., Wang, H. \& Yao, J. (2017). Oil prices and the global economy. International Monetary Fund. Retrieved from: https://www.imf.org/en/Publications/WP/Issues/2 017/01/27/Oil-Prices-and-the-Global-Economy44594

Bardi, U. (2009). Peak oil: The four stages of a new idea. Energy, 34(3), 323-326. doi: $\underline{10.1016 / j . e n e r g y .2008 .08 .015}$

Barsky, R. \& Kilian, L. (2004). Oil and the macroeconomy Since the 1970s. Journal of Economic Perspectives, 18(4), 115-134. doi: $10.3386 / \mathrm{w} 10855$

Blankart, C. B. (2017). Peak Oil Theory. Economic Ideas You Should Forget, 1, 27-28. doi: 10.1007/978-3319-47458-8_10

British Petroleum. (2015, December). Oil Prices.

Retrieved from: https://www.bp.com/en/global/corporate/energyeconomics/statistical-review-of-worldenergy/oil/oil-prices.html

British Petroleum. (2018, June). Statistical Review of World Energy 2018. Retrieved from: https://www.bp.com/en/global/corporate/energyeconomics/statistical-review-of-worldenergy.html
Cole, M. A. (2003). Environmental optimists, environmental pessimists and the real State of the world - an article examining The Skeptical Environmentalist: Measuring the Real State of the World. Economics Journal, 113, 362-380. Retrieved from: https://onlinelibrary.wiley.com/doi/epdf/10.1111/ $\underline{\text { 1468-0297.t01-1-00141 }}$

Eurostat Statistics Explained. (2016, 8 March). Glossary: Metric tons of Oil Equivalent (toe). Retrieved from http://ec.europa.eu/eurostat/statisticsexplained/ind ex.php/Glossary: Tonnes_of_oil_equivalent_(toe)

Fog, K. (2005). The real nature of the opposition against B. Lomborg. Journal of Information Ethics, 14(2), 66-76. doi:10.3172/JIE.14.1.16

Gohlz, E. \& Press, D. (2007). Energy alarmism: The myths that make Americans worry about oil (PA 589). Cato Institute Policy Analysis Series No. 589. doi: dx.doi.org/10.2139/ssrn.999649

Hekkert, M., Franka, H., Faaij, A. \& Neelis, M. (2005). Natural gas as an alternative to crude oil in automotive fuel chains well-to-wheel analysis and transition strategy development. Energy Policy, 33(5), 579-594. doi: https://doi.org/10.1016/j.enpol.2003.08.018

Lomborg, B. (2001). The Skeptical Environmentalist: Measuring the Real State of the World. Cambridge: Cambridge University Press.

McGee, J. (1958). Predatory price cutting: The standard oil (N.J.) case. The Journal of Law and Economics, 1, 137-169. Retrieved from: http://links.jstor.org/sici?sici=00222186\%281958 10\%291\%3C137\%3APPCTSO $\% 3 \mathrm{E} 2.0 . \mathrm{CO} \% 3 \mathrm{~B} 2$ $-4$

Morris, J. (2002). Sustainable development: Promoting progress or perpetuating poverty? Great Britain: Profile Books Ltd.

Muller, I. (2008). Evolving priorities: Canadian oil policy and the United States in the years leading up to the Oil Crisis of 1973. UWSPace. 1, 1-124. Retrieved from: https:/uwspace.uwaterloo.ca/bitstream/handle/10 012/3705/Ian\%20Muller\%20Thesis.pdf?sequence $=1 \&$ isAllowed $=\mathrm{y}$ 
Norgaard, R. B. (2002). Optimists, pessimists, and science. BioScience, 52(3), 287-292. doi: 10.1641/00063568(2002)052[0287:OPAS]2.0.CO;2

O'Rourke, D. \& Connolly, S. (2003). Just oil? The distribution of environmental and social impacts of oil production and consumption. Annual Review of Environment and Resources, 28, 587617. Doi: 10.1146/annurev.energy.28.0503 02.105617

Onwurrah, I. N. E., Ogugua, V. N., Onyike, N. B., Ochonogor, A. E. \& Otitoju, O. F. (2007). Crude oil spills in the environment, effects and some innovative clean-up biotechnologies.

International Journal of Environmental Research, 1(4), 307-320. Retrieved from: https://www.researchgate.net/publication/277943 50 Crude Oils Spills in the Environment Effe cts and Some Innovative Clean$\underline{\text { Up_Biotechnologies }}$

Organization of the Petroleum Exporting Countries (2001). Retrieved from:

http://www.opec.org/library/Annual\%20Statistica 1\%20Bulletin/interactive/2004/FileZ/definition.ht $\underline{\mathrm{m}}$

Pannell, D. (2011). Oil panic and the global crisis: Predictions and myths. The Australian Journal of Agricultural and Resource Economics, 55(2), 294-296. doi: https://doi.org/10.1111/j.1467$\underline{8489.2011 .00539 . x}$

Pimm, S. \& Harvey, J. (2001). No need to worry about the future. Nature, 414, 1-6 Retrieved from: http://www.landbrugph.dk/nature.pdf

Plains All American Pipeline. (2017, 29 December). Historical Bulletins for Plains Marketing.
Retrieved from

https:/Www.plainsallamerican.com/customercenter/crude-oil-bulletins/historical/plainsmarketing, $-1-p$

Rohlf, D. J. (2002). Revenge of the once-ler: The Skeptical Environmentalist. Case Western Reserve Law Review, 53(2), 297-313. Retrieved from: https://scholarlycommons.law.case.edu/cgi/viewc ontent.cgi?referer=https://www.google.ca/\&httpsr $\underline{\text { edir }=1 \& \text { article }=2661 \& \text { context }=\text { caselrev }}$

Simon, J. L. (1998). The Ultimate Resource 2. Maryland: Princeton University Press.

The Organization of Economic Cooperation and Development. (2018). Crude Oil Production. Retrieved from: https://data.oecd.org/energy/crude-oilproduction.htm

U.S. Energy Information Administration. (2018, 30 March). U.S. Field Production of Crude Oil. Independent Statistics \& Analysis. Retrieved from https://www.eia.gov/dnav/pet/hist/LeafHandler.as $\underline{\mathrm{hx}} \mathrm{n}=$ pet\&s$=$ mcrfpus $2 \& \mathrm{f}=\mathrm{a}$

Van Den Bergh, J. C. J. M. (2010). An assessment of Lomborg's The Skeptical Environmentalist and the ensuing debate. Journal of Integrative Environmental Sciences, 7(1), 23-52.doi: $10.1080 / 19438150903533730$

Watkins, G. C. (2006). Oil scarcity: What have the past three decades revealed? Energy Policy, 5, 508514. doi: 10.1016/j.enpol.2005.11.006

Worldwatch Institute (2018, 8 April). Mission. Retrieved from: http://www.worldwatch.org/mission 


\section{Tables and Figures}

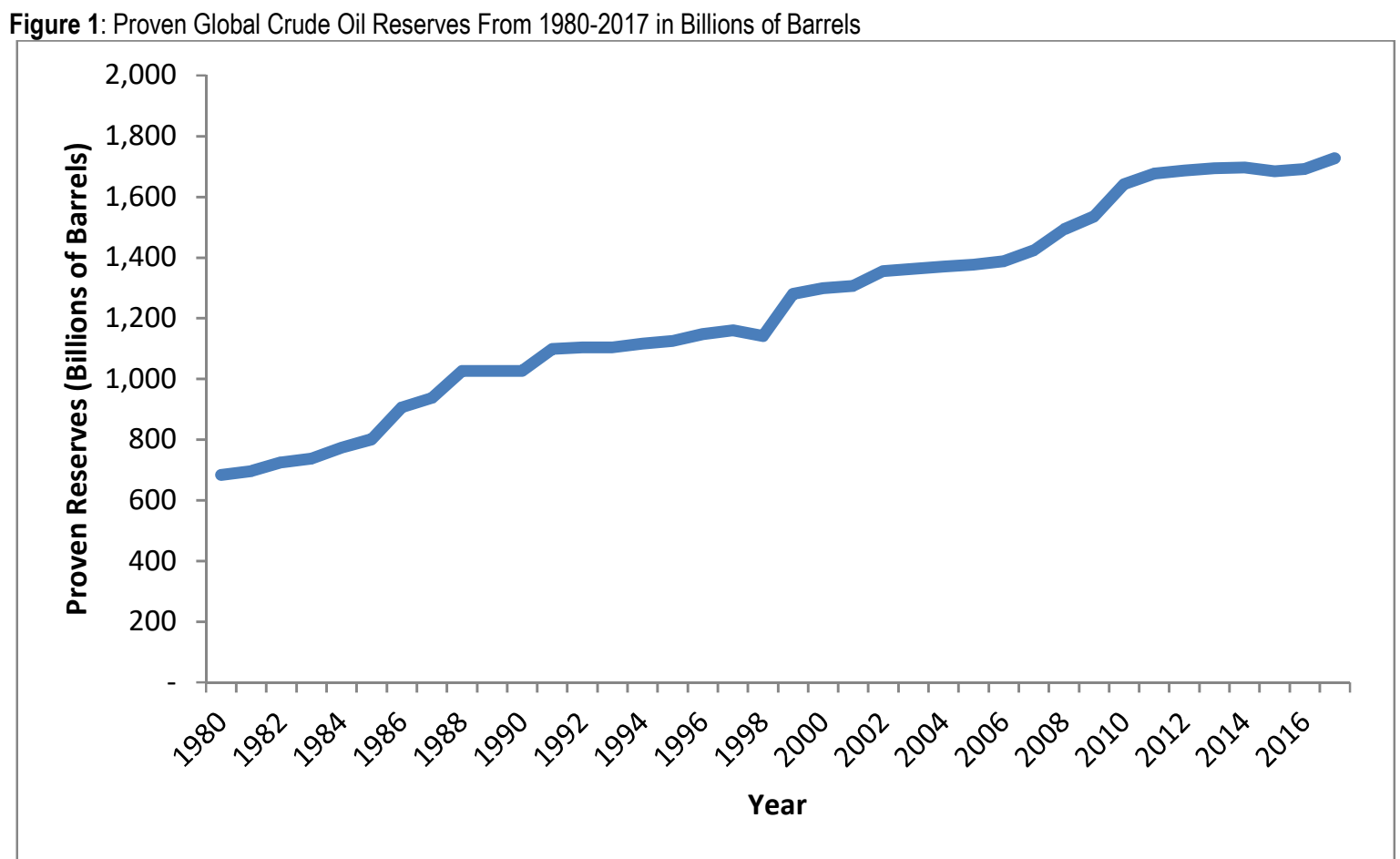

Source: British Petroleum (2018)

Notes:

1. Crude oil is unrefined petroleum found in the earth, made up of hydrocarbons and organic materials, which can be refined to make diesel fuels and gasoline.

2. Proven Reserves: Estimated quantity of hydrocarbons, defined as crude oil, which is thought to be readily recoverable in the future using current extraction techniques (Organization of the Petroleum Exporting Countries, 2001). 
Figure 2: Global Production of Crude Oil from 1972-2016 Measured in Thousand Metric tons of Oil Equivalent

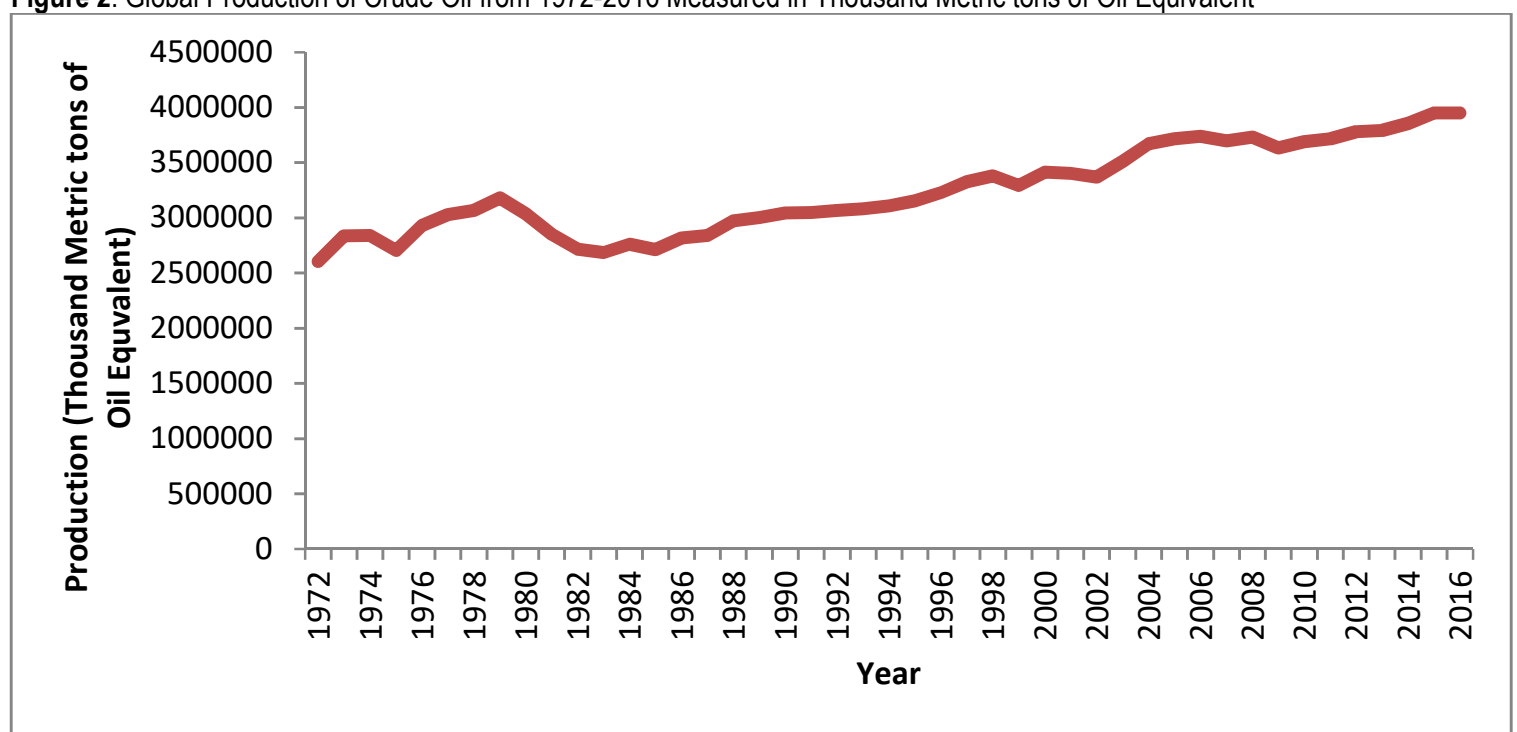

Source: The Organization of Economic Cooperation and Development (2018).

Notes:

1. Crude oil production is the quantity of oil extracted from reserves and refined into fuel and/or other oil-based products.

2. Thousand Metric Tons of oil equivalent is a unit of measurement designed to measure the amount of energy output per Metric Ton of metric oil burned (Eurostat, 2016). 
Figure 3: Nominal vs. Constant U.S. Crude Oil Prices (\$USD/Barrel) From 1861-2017

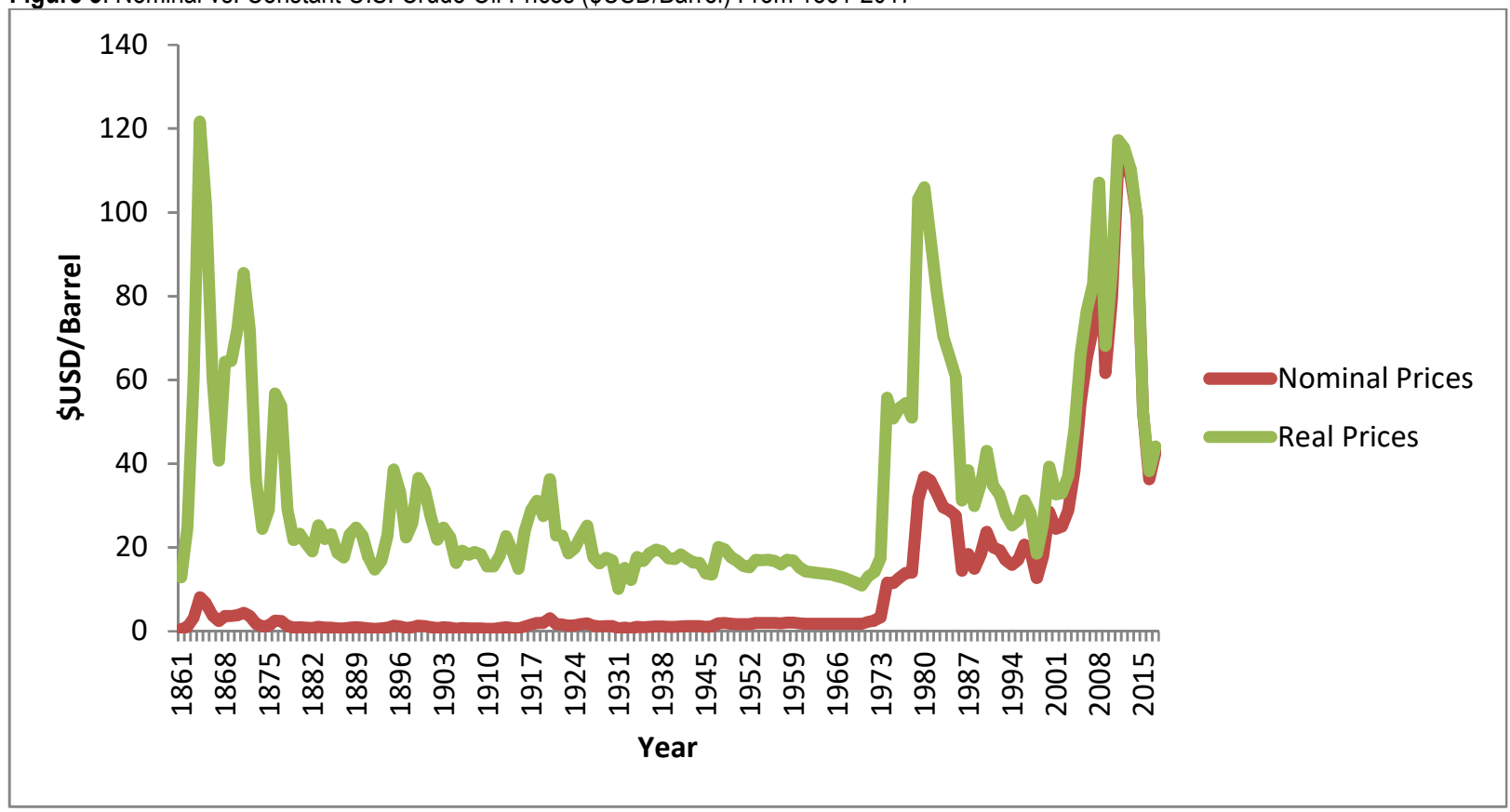

Source: British Petroleum (2015), Plains All American Pipeline (2017)

Notes:

1. All prices are in U.S. Dollars (\$USD) per barrel.

2. 1 barrel of crude oil equals 42 gallons.

3. Constant prices are calculated for a base year of 2017.

4. Constant prices are prices that are adjusted for inflation by dividing the nominal (current dollar) price by the consumer price index (CPI) for that year.

5. In this case, a real price calculator was used to input the inflation-adjusted price values for 2016 and 2017 , as the constant prices were not included in the data set.

6. Prices quoted reflect average prices of Brent, West Texas Intermediate (WTI), Nigerian Focados, and Dubai in \$USD per barrel. 